\title{
Comparison of Axillary Lymph Node Dissection by Using Ligasure Vessel Sealing System Vs Conventional Thread Ligation in Patients Undergoing Modified Radical Mastectomy for Carcinoma of Breast
}

\author{
Ayesha Shaukat', Muhammad Ayyub Anjum² \\ 1,2Department of Surgery, West Surgical Ward, King Edward Medical University /Mayo Hospital, Lahore-Pakistan
}

\begin{abstract}
Background: Breast Cancer is very common among women in Pakistan. Unfortunately, in our country patients present at late stage in teaching hospitals due to lack of awareness and traditional false beliefs. At this late stage modified radical mastectomy is the most common procedure carried out in our public sector hospitals. Traditional thread ligation is time consuming for axillary dissection. The modern vessel sealing devices are available. We aimed to compare the vessel sealing device Ligasure with the conventional method for axillary dissection during modified radical mastectomy. Objective: To compare conventional thread ligation method versus ligasure vessel sealing system use in axillary dissection for carcinoma breast in terms of mean post-operative drain output and mean number of days till drain removal. Study Design: Randomized Controlled Trial. Settings: The study was conducted in Department of Surgery, KEMU/ Mayo Hospital, Lahore-Pakistan. Duration: Seven months from 13-11-2018 to 13-05 2019. Methodology: After patients meeting inclusion criteria, they were prepared and underwent surgery. Patients were divided in two groups (group $A$ and group B) Group-A patients underwent axillary dissection using Ligasure vessel sealing system while group-B patients underwent axillary dissection using traditional thread ligation. Drain outputs were recorded in Milliliters daily till drain output becomes less than $20 \mathrm{ml}$ in preceding 24 hours. Drain removal day was noted. Data were analyzed using SPSS v20.0. t-test was used to compare the mean drain output and mean total number of days till drain removal in both groups. Data were stratified for age, BMI and tumor size to deal with effect modifiers. Post-stratification, t-test was applied. A pvalue $\leq 0.05$ was considered statistically significant. Results: A total of 112 patients were enrolled for this study. Patients were divided into two groups i.e. Group-A (Ligasure System) and Group-B (Conventional Method). In group-A, mean age was $45.8 \pm 18.2$ years and $50.1 \pm 18.2$ years in group-B. In group-A, mean drain volume was $500.1 \pm 60.8 \mathrm{ml}$ and $665.3 \pm 84.9 \mathrm{ml}$ in group-B with a p-value of 0.0001 , which is statistically significant. In group-A, mean number of days till drain removal was $6.5 \pm 1.1$ and $8.6 \pm 1.2$ in group-B with a p-value of 0.0001 , which is statistically significant. Conclusion: Axillary Lymph node dissection using Ligasure leads to decrease in mean post-operative drain output and mean number of days till drain removal as compared to conventional thread ligation method.
\end{abstract}

Keywords: Breast Cancer, Ligasure vessel sealing system, Traditional thread ligation.

Corresponding Author

Submitted for Publication: 05-05-2020

Dr. Ayesha Shaukat, Professor of Surgery, West Surgical Ward, King Edward Medical University/ Mayo Hospital, Lahore-Pakistan.

Email: ayesha_surg@hotmail.com

Citation: Shaukat A, Anjum MA. Comparison of Axillary Lymph Node Dissection by Using Ligasure Vessel Sealing System Vs Conventional Thread

Ligation in Patients Undergoing Modified Radical Mastectomy for Carcinoma of Breast. APMC 2020;14(3):254-8.

DOI: $10.29054 / A P M C / 2020.925$

\section{INTRODUCTION}

Cancer is the leading cause of mortality and morbidity. Worldwide. There were 14.1 million new cancer cases and total number of deaths estimated to result from cancer was 8.2 million. There were 1.7 million new cases of breast cancer in 2012.Breast Cancer is most common cause of cancer deaths in females. ${ }^{1}$ A study in Pakistan also showed that breast cancer is the most common cancer in Pakistan accounting for $38.2 \%$ of all the cancers and these rates are highest in Asia. ${ }^{2}$ Most of the females with Breast cancer in Pakistan present late. According to a study, $80 \%$ of the females presented with a delay of greater than three months and delay was found out to be due to traditional beliefs and false symptom interpretation. ${ }^{3}$

Surgery remains the mainstay of treatment of breast cancer and if the axillary lymph nodes are also found to be involved modified radical mastectomy is the treatment of choice. ${ }^{4}$ Two drains are placed traditionally one in flap and one in axilla after modified radical mastectomy. There are different surgical techniques and instruments compared in studies for axillary lymph node dissection ranging from traditional electrocautery and thread ligation and harmonic scalpel. ${ }^{5}$ Heavy post-operative drain output and seroma formation is the most common complication seen after modified radical mastectomy with axillary clearance using traditional thread ligation techniques. ${ }^{6}$

Studies have documented that the new Ligasure electro thermal bipolar vessel sealing system is safe to use in axillary clearance as an alternative to traditional methods and it reduces postoperative drain output $(620 \pm 469 \mathrm{ml}$ vs. $809 \pm 380 \mathrm{ml})$ and duration of drain till removal (7.6 \pm 4.6 days vs. $10 \pm 4.3$ days). ${ }^{7}$ Ligasure used in axillary dissection reduces postoperative complications and allows early drain removal (4.3 \pm 1.0 days vs. $5.7 \pm 1.5$ days) and less drain output $(366.2 \pm 220.1 \mathrm{ml}$ vs. $422.9 \pm 225.5 \mathrm{ml}$ ) as compared to traditional methods of thread ligation. ${ }^{8}$ In another study, it was concluded that Ligasure is more effective device compared to traditional methods in axillary dissection in terms of reducing total volume of fluid drainage 
( $365.3 \pm 242.2$ vs. $625.1 \pm 446.6 \mathrm{ml})$ and number of days till drain removal ( $6.4 \pm 2.9$ vs. $8.2 \pm 3.8$ days). ${ }^{9}$

Rationale for conducting this clinical trial is to test the Ligasure against conventional methods of axillary dissection for its usefulness and stated benefits in our system considering the burden of breast cancer disease and large number of modified radical mastectomies being carried out with conventional techniques. The results of this clinical trial using this new instrument and technique will add to the existing body of knowledge. They may be used by policy makers, planners and health managers to institute meaningful resources for provision of this instrument and technique to all levels. The results will also create awareness among health care professionals regarding this new instrument and technique.

\section{METHODOLOGY}

Study Design: Randomized Controlled Trial.

Settings: The study was conducted in Department of Surgery, KEMU/ Mayo Hospital, Lahore Pakistan.

Duration: Seven months from 13-11-2018 to 13-05 2019.

Sample Technique: Non-Probability Consecutive Sampling.

Sample Size: The sample size of 112(56 in each group) was estimated by using $95 \%$ confidence level with $80 \%$ power of test and taking expected mean number of days till drain removal $6.4 \pm 2.9$ days with ligasure method and $8.2 \pm 3.8$ days with conventional method. ${ }^{9}$

Inclusion Criteria: Female gender, Patient of 18-80 years of age, Patients with unilateral breast carcinoma (histopathological diagnosis using trucut biopsy) with all indications of modified radical mastectomy (clinical and radiological evidence of axillary lymph node involvement and American society of anesthesiology scores 1 and 2 was included in the study.

Exclusion Criteria: Patients with early breast cancer (T1), history of previous breast surgeries e.g. recurrent carcinoma, patients with diabetes mellitus, patients on anticoagulants, patients with radiation therapy to chest wall, patients with any type of neo adjuvant chemotherapy, ASA scores III and IV and stage IV metastatic carcinoma were excluded.

Data Collection Procedure: After approval from Hospitals Ethics Committee Mayo Hospital Lahore, written informed consent from each patient meeting inclusion criteria and undergoing surgery was taken.

A detailed history was taken from each patient including demographic data like age, body mass index, height etc. They were assured confidentiality and explained about expertise available for new technique and conventional technique.

Operation was performed by same group of surgeons. Tumor was staged using TNM classification. Patients were divided in two groups (group A and group B) randomly using random number tables. Blinding was be done.

Group-A patients underwent axillary dissection using Ligasure vessel sealing system while group-B patients underwent axillary dissection using traditional thread ligation.

Pre-operative preparation was done by complete bath prior to surgery using antiseptic soap and axilla was shaved. All the baseline investigations including routine radiological investigations and metastatic workup were carried out for each patient in both groups.

All of patients were given prophylactic antibiotics preoperatively. The surgeries were performed under general anesthesia. Level I, II lymph node dissection was done in all cases depending upon involvement of the axillary lymph nodes. Two suction drains were placed one in axilla and one in flap and they were called Axillary drain and Flap drain, respectively.

Drain outputs were recorded in Milliliters daily till drain output becomes less than $20 \mathrm{ml}$ in preceding 24 hours. Each drain was removed when drain output becomes less than $20 \mathrm{ml}$ in the preceding 24 hours. Drain removal day was noted and analyzed separately for each drain. Patients were discharged after removal of drains. Patients were called after $7^{\text {th }}$ to $10^{\text {th }}$ postoperative day in Outpatient Department and underwent thorough examination and investigations for any complication. If any positive finding was seen it was recorded. Stitches were removed on post-operative day 10 . In all patients, the following data were recorded: age, body mass index (BMI), type of surgery, duration of drain and amount of drained fluid. All data were recorded by me on a specially designed proforma (attached).

Data Analysis: Data were analyzed using SPSS v23.0. Mean \pm S.D. was used for quantitative data like age, amount of drainage from both drains, number of days till drain removal. ttest was used to compare the mean drain output and mean total number of days till drain removal in both groups. Poststratification, t-test was applied. A p-value $\leq 0.05$ was considered statistically significant.

\section{RESULTS}

A total of 112 patients were enrolled for this study. Patients were divided into two groups i.e. Group-A (Ligasure System) and Group-B (Conventional Method).

In group-A, $13(23.2 \%)$ patients were in 18-30 years age group, while $13(23.2 \%)$ and $30(53.6 \%)$ were in $31-45$ and $>45$ years age groups respectively. In group-B, $7(12.5 \%)$ patients were in $18-30$ years age group, while $19(33.9 \%)$ and $30(53.6 \%)$ were in $31-45$ and $>45$ years age groups respectively. In group- $A$, mean age was $45.8 \pm 18.2$ years and $50.1 \pm 18.2$ years in group-B.

In group-A, $29(51.8 \%)$ patients had normal $\mathrm{BMI}$, while $25(44.6 \%)$ and $2(3.6 \%)$ overweight and obese respectively. In group-B, 31(55.4\%) patients had normal BMI, while 24(42.9\%) and $1(1.8 \%)$ overweight and obese respectively.

In group-A, 38(67.9\%) patients had tumor size $<2 \mathrm{~cm}$, while $18(32.1 \%)$ had tumor size $\geq 2 \mathrm{~cm}$. In group-B, 30(53.6\%) patients had tumor size $<2 \mathrm{~cm}$, while $26(46.4 \%)$ had tumor size $\geq 2 \mathrm{~cm}$.

In group- $A$, mean drain volume was $500.1 \pm 60.8 \mathrm{ml}$ and $665.3 \pm 84.9 \mathrm{ml}$ in group-B with a p-value of 0.0001 , which is statistically significant.

In group-A, mean number of days till drain removal was $6.5 \pm 1.1$ and $8.6 \pm 1.2$ in group-B with a $p$-value of 0.0001 , which is statistically significant. 
Table 1: Comparison of age distribution between groups

\begin{tabular}{|c|c|c|c|}
\hline \multirow{2}{*}{$\begin{array}{c}\text { Age } \\
\text { groups }\end{array}$} & \multicolumn{2}{|c|}{ Groups } & \multirow{2}{*}{ Total } \\
\cline { 2 - 3 } & Ligasure System & Conventional Method & \\
\hline $\begin{array}{c}18-30 \\
\text { years }\end{array}$ & 13 & 7 & 20 \\
\cline { 2 - 3 } & $23.2 \%$ & $12.5 \%$ & $17.9 \%$ \\
\hline $\begin{array}{c}31-45 \\
\text { years }\end{array}$ & 13 & 19 & 32 \\
\cline { 2 - 3 } $\begin{array}{c}>45 \\
\text { years }\end{array}$ & $23.2 \%$ & $33.9 \%$ & $28.6 \%$ \\
\cline { 2 - 3 } Total & 30 & 30 & 60 \\
\cline { 2 - 3 } & $56.6 \%$ & $53.6 \%$ & $53.6 \%$ \\
\hline
\end{tabular}

Table 2: Comparison of BMI distribution between groups

\begin{tabular}{|c|c|c|c|}
\hline \multirow{2}{*}{$\begin{array}{c}\text { Body Mass } \\
\text { Index (BMI) }\end{array}$} & \multicolumn{2}{|c|}{ Groups } & \multirow{2}{*}{ Total } \\
\cline { 2 - 3 } & Ligasure System & Conventional Method & \\
\hline $\begin{array}{c}\text { Normal } \\
(18-24.9)\end{array}$ & 29 & 31 & 60 \\
\cline { 2 - 4 } & $51.8 \%$ & $55.4 \%$ & $53.6 \%$ \\
\hline $\begin{array}{c}\text { Overweight } \\
(25-29.9)\end{array}$ & 25 & 24 & 49 \\
\cline { 2 - 4 } & $44.6 \%$ & $42.9 \%$ & $43.8 \%$ \\
\hline $\begin{array}{c}\text { Obese } \\
(>30)\end{array}$ & 2 & 1 & 3 \\
\cline { 2 - 4 } Total & $3.6 \%$ & $1.8 \%$ & $2.7 \%$ \\
\cline { 2 - 4 } & $100.0 \%$ & 56 & 112 \\
\hline \multirow{2}{*}{} & \multicolumn{3}{|c}{} \\
\hline
\end{tabular}

Table 3: Comparison of tumor size distribution between groups

\begin{tabular}{|c|c|c|c|}
\hline \multirow{2}{*}{$\begin{array}{c}\text { Tumor size } \\
(\mathbf{c m})\end{array}$} & \multicolumn{2}{|c|}{ Groups } & \multirow{2}{*}{ Total } \\
\cline { 2 - 4 }$<2 \mathrm{~cm}$ & Ligasure System & Conventional Method & \\
\cline { 2 - 4 } & 38 & 30 & 68 \\
\hline \multirow{2}{*}{$\geq 2 \mathrm{~cm}$} & $67.9 \%$ & $53.6 \%$ & $60.7 \%$ \\
\cline { 2 - 4 } & 18 & 26 & 44 \\
\hline \multirow{2}{*}{ Total } & $32.1 \%$ & $46.4 \%$ & $39.3 \%$ \\
\cline { 2 - 4 } & 56 & 56 & 112 \\
\hline
\end{tabular}

Table 4: Comparison of drain volume between groups

\begin{tabular}{|c|c|c|c|c|c|}
\hline \multirow{3}{*}{$\begin{array}{c}\text { Drain } \\
\text { Volume (ml) }\end{array}$} & Groups & $\mathbf{n}$ & Mean & SD & p-value \\
\cline { 2 - 6 } & Ligasure System & 56 & 500.13 & 60.87 & \multirow{2}{*}{0.0001} \\
\cline { 2 - 6 } & Conventional Method & 56 & 665.38 & 84.93 & \\
\hline
\end{tabular}

SD = Standard Deviation

Table 5: Comparison of number of days till drain removal between groups

\begin{tabular}{|c|c|c|c|c|c|}
\hline \multirow{2}{*}{$\begin{array}{c}\text { Number of } \\
\text { days till drain } \\
\text { removal }\end{array}$} & Groups & $\mathbf{N}$ & Mean & SD & p-value \\
\cline { 2 - 6 } & Ligasure System & 56 & 6.50 & 1.01 & \multirow{2}{*}{0.0001} \\
\cline { 2 - 6 } & Conventional Method & 56 & 8.66 & 1.12 & \\
\hline
\end{tabular}

$\mathrm{SD}=$ Standard Deviation
Table 6: Stratification of comparison of drain volume with respect to age groups

\begin{tabular}{|c|c|c|c|c|c|c|}
\hline \multirow{7}{*}{\begin{tabular}{|c} 
Drain \\
Volume \\
(ml)
\end{tabular}} & $\begin{array}{c}\text { Age } \\
\text { groups }\end{array}$ & Groups & $n$ & Mean & SD & $\begin{array}{c}\text { p- } \\
\text { value }\end{array}$ \\
\hline & $18-30$ & Ligasure System & 13 & 491.62 & 57.78 & \multirow{2}{*}{-0.00} \\
\hline & years & Conventional Method & 7 & 681.57 & 116.36 & \\
\hline & \multirow{2}{*}{$\begin{array}{l}31-45 \\
\text { years }\end{array}$} & Ligasure System & 13 & 487.00 & 62.77 & \multirow{2}{*}{0.0001} \\
\hline & & Conventional Method & 19 & 688.42 & 78.96 & \\
\hline & \multirow{2}{*}{$\begin{array}{c}>45 \\
\text { years }\end{array}$} & Ligasure System & 30 & 509.50 & 61.76 & \multirow{2}{*}{0.001} \\
\hline & & Conventional Method & 30 & 647.00 & 79.05 & \\
\hline
\end{tabular}

SD = Standard Deviation

Table 7: Stratification of comparison of number of days till drain removal with respect to age groups

\begin{tabular}{|c|c|c|c|c|c|c|}
\hline \multirow{7}{*}{$\begin{array}{l}\text { Number of } \\
\text { days till } \\
\text { drain } \\
\text { removal }\end{array}$} & $\begin{array}{c}\text { Age } \\
\text { groups }\end{array}$ & Groups & $n$ & Mean & SD & $\begin{array}{c}\text { p- } \\
\text { value }\end{array}$ \\
\hline & $18-30$ & Ligasure System & 13 & 6.38 & 0.87 & \multirow{2}{*}{0.00} \\
\hline & years & Conventional Method & 7 & 9.14 & 0.90 & \\
\hline & $31-45$ & Ligasure System & 13 & 6.31 & 1.03 & \multirow{2}{*}{0.001} \\
\hline & $\begin{array}{l}11-45 \\
\text { years }\end{array}$ & Conventional Method & 19 & 8.74 & 1.28 & \\
\hline & \multirow{2}{*}{$\begin{array}{c}>45 \\
\text { years }\end{array}$} & Ligasure System & 30 & 6.63 & 1.07 & \multirow{2}{*}{0.00} \\
\hline & & Conventional Method & 30 & 8.50 & 1.04 & \\
\hline
\end{tabular}

SD = Standard Deviation

Table 8: Stratification of comparison of drain volume with respect to Body Mass Index (BMI)

\begin{tabular}{|c|c|c|c|c|c|c|}
\hline \multirow{7}{*}{$\begin{array}{c}\text { Drain } \\
\text { Volume } \\
\text { (ml) }\end{array}$} & BMI & Groups & $n$ & Mean & SD & $\begin{array}{c}\mathrm{p}- \\
\text { value }\end{array}$ \\
\hline & \multirow{2}{*}{$\begin{array}{c}\text { Normal } \\
(18-24.9)\end{array}$} & Ligasure System & 29 & 512.59 & 51.59 & \multirow{2}{*}{0.0001} \\
\hline & & Conventional Method & 31 & 674.74 & 87.39 & \\
\hline & \multirow{2}{*}{$\begin{array}{c}\text { Overweigh } \\
(25-29.9)\end{array}$} & Ligasure System & 25 & 488.08 & 69.02 & \multirow{2}{*}{0.001} \\
\hline & & Conventional Method & 24 & 658.08 & 80.83 & \\
\hline & \multirow{2}{*}{$\begin{array}{l}\text { Obese } \\
(>30)\end{array}$} & Ligasure System & 2 & 470.00 & 70.71 & \multirow{2}{*}{0.525} \\
\hline & & Conventional Method & 1 & 550.00 & 55.62 & \\
\hline
\end{tabular}

$\mathrm{SD}=$ Standard Deviation

Table 9: Stratification of comparison of number of days till drain removal with respect to Body Mass Index (BMI)

\begin{tabular}{|c|c|c|c|c|c|c|}
\hline \multirow{7}{*}{$\begin{array}{l}\text { Number } \\
\text { of days } \\
\text { till drain } \\
\text { removal }\end{array}$} & BMI & Groups & $n$ & Mean & SD & $p$-value \\
\hline & \multirow{2}{*}{$\begin{array}{c}\text { Normal } \\
(18-24.9)\end{array}$} & Ligasure System & 29 & 6.38 & 1.08 & \multirow[b]{2}{*}{0.00003} \\
\hline & & $\begin{array}{l}\text { Conventional } \\
\text { Method }\end{array}$ & 31 & 8.65 & |1.17 & \\
\hline & \multirow{2}{*}{$\begin{array}{c}\text { Overweight } \\
(25-29.9)\end{array}$} & Ligasure System & 25 & 6.64 & 0.95 & \multirow[b]{2}{*}{0.0012} \\
\hline & & $\begin{array}{l}\text { Conventional } \\
\text { Method }\end{array}$ & 24 & 8.75 & 1.03 & \\
\hline & \multirow{2}{*}{$\begin{array}{l}\text { Obese } \\
(>30)\end{array}$} & Ligasure System & 2 & 6.50 & 0.71 & \multirow[b]{2}{*}{0.667} \\
\hline & & $\begin{array}{l}\text { Conventional } \\
\text { Method }\end{array}$ & 1 & 7.00 & 1.52 & \\
\hline
\end{tabular}

$\mathrm{SD}=$ Standard Deviation 
Table 10: Stratification of comparison of drain volume with respect to tumor size

\begin{tabular}{|c|c|c|c|c|c|c|}
\hline \multirow{4}{*}{$\begin{array}{c}\text { Drain } \\
\text { Volume } \\
\text { (ml) }\end{array}$} & $\begin{array}{c}\text { Tumor } \\
\text { size }(\mathbf{c m})\end{array}$ & Groups & $\mathbf{n}$ & Mean & SD & $\begin{array}{c}\mathbf{p}- \\
\text { value }\end{array}$ \\
\cline { 2 - 7 } & $<2 \mathrm{~cm}$ & Ligasure System & 38 & 507.53 & 61.70 & 0.0001 \\
\cline { 2 - 7 } & 2 Conventional Method & 30 & 674.60 & 83.18 & \\
\cline { 2 - 7 } & $\geq 2 \mathrm{~cm}$ & Ligasure System & 18 & 484.50 & 57.63 & 0.0013 \\
\cline { 2 - 7 } & & Conventional Method & 26 & 654.73 & 87.31 & \\
\hline
\end{tabular}

SD = Standard Deviation

Table 11: Stratification of comparison of number of days till drain removal with respect to tumor size

\begin{tabular}{|l|c|c|c|c|c|c|}
\hline \multirow{4}{*}{$\begin{array}{l}\text { Number } \\
\text { of days } \\
\text { till drain }\end{array}$} & $\begin{array}{c}\text { Tumor } \\
\text { size }(\mathbf{c m})\end{array}$ & Groups & $\mathbf{n}$ & Mean & SD & $\begin{array}{c}\text { p- } \\
\text { value }\end{array}$ \\
\cline { 2 - 7 } removal & $<2 \mathrm{~cm}$ & Ligasure System & 38 & 6.53 & 0.86 & \multirow{2}{*}{0.001} \\
\cline { 2 - 7 } & & Conventional Method & 30 & 8.70 & 1.09 & \\
\cline { 2 - 7 } & $\geq 2 \mathrm{~cm}$ & Ligasure System & 18 & 6.44 & 1.29 & \multirow{2}{*}{0.0002} \\
\cline { 2 - 6 } & & Conventional Method & 26 & 8.62 & 1.17 & \\
\hline
\end{tabular}

SD = Standard Deviation

\section{DISCUSSION}

Breast cancer is the most frequently encountered kind of tumor spotted in women worldwide. It is responsible for $32 \%$ of feminine cancers and $19 \%$ of deaths related to cancer. One woman out of eight in the USA and one woman out of ten in European countries has breast cancer.

The most important parameter in the prognosis of breast cancer is whether there is axillary lymph node involvement or not. Axillary lymph node dissection is performed for accurate staging of the disease, directing adjuvant therapies, and providing local tumor control in patients with lymph node involvement. Following axillary curettage, seroma is seen between $10 \%$ and $80 \%$, and it necessitates aspirating. ${ }^{10}$

LigaSure bipolar vessel sealing system provides haemostasis of vessels between 1 and 7 millimetres. LigaSure vessel sealing system transfers the appropriate amount of energy in tissue lumps or vessels according to their densities. Thus, as no exceeding energy is transferred, thermal convectional damage is limited to neighbouring tissues.

With Ligasure, thermal radiation to nearby tissues is between 0.5 and 2 millimetres. With LigaSure Precise, which we use in axillary curettage, radiation is below 0.5 millimetres. ${ }^{11,12}$

Previous randomized studies comparing the vessel sealing system with conventional devices have reported that vessel sealing system seems to reduce the drainage volume and shorten the postoperative hospital days. ${ }^{13,14,15}$

Our study shows that the use of the LigaSure Small Jaw reduced the days until drain removal and postoperative drainage volume when comparing to the conventional devices. It is extremely important to shorten drain days and hospital stay, because delays in these factors can lead to delays in adjuvant therapy.

In this study, after subgroup analysis, the vessel sealing system seems to be more effective in the patients with age under 60 years, and BMI less than 25. However, this was not conclusive because of the limited sample size.

In this study, in ligasure group, mean drain volume was $500.1 \pm 60.8 \mathrm{ml}$ and $665.3 \pm 84.9 \mathrm{ml}$ in conventional group with a p-value of 0.0001 , which is statistically significant. In ligasure group, mean number of days till drain removal was $6.5 \pm 1.1$ and $8.6 \pm 1.2$ in conventional group with a p-value of 0.0001 , which is statistically significant.

Studies have documented that the new Ligasure electro thermal bipolar vessel sealing system is safe to use in axillary clearance as an alternative to traditional methods and it reduces postoperative drain output $(620 \pm 469 \mathrm{ml}$ vs. $809 \pm 380 \mathrm{ml})$ and duration of drain till removal ( $7.6 \pm 4.6$ days vs. $10 \pm 4.3$ days). ${ }^{7}$ Ligasure used in axillary dissection reduces postoperative complications and allows early drain removal $(4.3 \pm 1.0$ days vs. $5.7 \pm 1.5$ days) and less drain output $(366.2 \pm 220.1 \mathrm{ml}$ vs. $422.9 \pm 225.5 \mathrm{ml}$ ) as compared to traditional methods of thread ligation. ${ }^{8}$

In another study, it was concluded that Ligasure is more effective device compared to traditional methods in axillary dissection in terms of reducing total volume of fluid drainage $(365.3 \pm 242.2$ vs. $625.1 \pm 446.6 \mathrm{ml})$ and number of days till drain removal ( $6.4 \pm 2.9$ vs. $8.2 \pm 3.8$ days). ${ }^{9}$

\section{CONCLUSION}

Axillary Lymph node dissection using Ligasure leads to decrease in mean post-operative drain output and mean number of days till drain removal as compared to conventional thread ligation method.

\section{LIMITATIONS}

The major limitation we faced while conducting this study was to find patients meeting our inclusion criteria because most of the patients in our hospital present at a very late stage in which we had to first give neo adjuvant therapy and those patients could not meet our inclusion criteria. The second thing was availability of the Ligasure and the cost of the procedure but it was resolved by the hospital administration in the vital interest of the patients.

\section{SUGGESTIONS / RECOMMENDATIONS}

We should work hard to create awareness among the population regarding breast cancer. Government should make breast Clinics in all Primary and Secondary Healthcare settings so that patients are timely screened and managed at an earlier stage. There should be regular walks and seminars on breast cancer. The doctors at Basic Health Unit Level to DHQs should be given regular trainings for screening and proper referral of breast cancer patients.

\section{CONFLICT OF INTEREST / DISCLOSURE}

We have no conflict of interest and no disclosure regarding this trial with anyone. 


\section{ACKNOWLEDGEMENTS}

We are thankful to the Department of West Surgical Ward and its all residents and consultants who support us and helped us conducting this clinical trial. We are especially thankful to the Mayo Hospital Lahore administrations for readily providing Ligasure vessel sealing device free of cost to conduct our trial.

\section{REFERENCES}

1. Ferlay J. Soerjomataram I, Dikshit R, Eser S, Mathers C, Rebelo $\mathrm{M}$ et al. Cancer incidence and mortality worldwide: Sources, methods and major patterns in GLOBOCAN 2012. Int J Cancer. 2015;136(5):359-86.

2. Hanif M, Zaidi P, Kamal S, Hameed A. Institution-Based Cancer Incidence in a Local Population in Pakistan: Nine Year Data Analysis. Asian Pac J Cancer Prev. 2009;10(2):227-30.

3. Maryam AK, Muhammad IK, Uzma A. Patient Delay and Associated Factors Among Breast Cancer Patients. Rawal Med J. 2015;40(4):445-8.

4. Nai-si H, Meng-ying L, Jia-Jian C. Surgical management of breast cancer in china. Medicine (Baltimore) 2016;95(45):4201.

5. Allah A, Sadaf W, Ahsan k. Harmonic scalpel versus electrocautery in axillary dissection in carcinoma breast. J Coll Physicians Surg Pak. 2015;25(12):870-3.

6. Farkhanda JD, Muhammad SA, Abdul RQ. Early wound complications following modified radical mastectomy with axillary clearance. J Surg Pakistan. 2011;16(4):165-9.

7. Tukenmez M, Agcaoglu O, Aksakal N. The use of ligasure vessel sealing system in axillary dissection: effect on seroma formation. Chirurgia (bucur). 2014;109(5):620-5.

8. Cortadellas T, Córdoba $\mathrm{O}$, Espinosa-Bravo M. Electrothermal bipolar vessel sealing system in axillary dissection: a prospective randomized clinical study. Int J Surg. 2011;9(8):636-40.

9. Tomko S, Tetsku H, Maiko T. A randomized controlled study comparing a vessel sealing system with a conventional technique in axillary lymph node dissection for primary breast cancer. Springeplus. 2016;5(1):1004.

10. Pogson CJ, Adwani A, Ebbs SR. Seroma following breast cancer surgery. Eur J Surg Oncol. 2013;29(9):711-7.

11. Peterson SL, Stranahan PL, Schmaltz D, Mihaichuk C, Cosgriff N. Comparison of healing process following ligation with sutures and bipolar vessel sealing. Surg Technol Int. 2012;10:55-60.

12. Heniford BT, Matthews BD, Sing RF, Backus C, Pratt B, Greene FL. Initial results with an electrothermal bipolar vessel sealer. Surg Endosc. 2011;15(8):799-801.

13. Cortadellas $T$, Cordoba $O$, Espinosa-Bravo M, Mendoza-Santin C, Rodriguez- Fernandez J, Esgueva A, Alvarez-Vinuesa M, Rubio IT, Xercavins J. Electrothermal bipolar vessel sealing system in axillary dissection: a prospective randomized clinical study. Int J Surg. 2011;9(8):636-40.

14. Nespoli L, Antolini L, Stucchi C, Nespoli A, Valsecchi MG, Gianotti L. Axillary lymphadenectomy for breast cancer. A randomized controlled trial comparing a bipolar vessel sealing system to the conventional technique. Breast 2012;21(6):739-45.

15. Tukenmez M, Agcaoglu O, Aksakal N, Destek S, Cabioglu N, Barbaros U, Erbil Y, Bozbora A, Dinccag A, Ozmen V et al. The use of Ligasure vessel sealing system in axillary dissection; effect on seroma formation. Chirurgia (Bucur). 2014;109(5):620-5.

\section{AUTHORSHIP CONTRIBUTION}

\begin{tabular}{|l|l|}
\hline Dr. Ayesha Shaukat & \\
Professor of Surgery, West & \\
Surgical Ward, King Edward & Manuscript Writing, Critical Review \\
Medical University/ Mayo & \\
Hospital Lahore Pakistan & \\
\hline Dr. Muhammad Ayyub Anjum & \\
Trainee Registrar, West & \multirow{2}{*}{ Data Collection } \\
Surgical Ward, King Edward & \\
Medical University /Mayo & \\
Hospital Lahore Pakistan & \\
\hline
\end{tabular}

